\title{
39. INDIGENOUS AND REWORKED COCCOLITHS FROM THE BLACK SEA
}

\author{
Stephen F. Percival, Jr., Stratigraphic Laboratory, \\ Mobil Exploration \& Producing Services, Inc., Dallas, Texas
}

\begin{abstract}
Indigenous species of coccoliths rarely occur in samples studied from the subsurface of the Black Sea. Most of the occurrences of calcareous nannoplankton are of reworked Cretaceous and Eocene to Oligocene species. Rare occurrences of reworked Paleocene and Miocene-Pliocene species are also noted.

Indigenous species are restricted to three types of nannoflora: (1) an Emiliania huxleyi flora, (2) a Gephyrocapsa caribbeanica flora, and (3) a Braarudosphaera bigelowi flora. These floras are characterized by the nominal species almost to the exclusion of other indigenous forms. Also, the floras are most often associated with reworked Cretaceous and Eocene to Oligocene species. The Emiliania huxleyi flora was found only at Site 379 . The Gephyrocapsa caribbeanica flora was observed in about a 100-meter-thick section at the top of the cored interval at Sites 379 and 380 . The Braarudosphaera bigelowi flora was found in thin zones at all three sites-379, 380, and 381. Only the Emiliania huxleyi and Gephyrocapsa caribbeanica floras can be dated. The former is late Quaternary in age and is assigned to the NN 21 Emiliania huxleyi Zone of Martini (1971). The latter is Quaternary in age.
\end{abstract}

\section{DISCUSSION}

Light microscope examination of 245 samples from Site 379, 342 samples from Site 380 , and 141 samples from Site 381 was conducted for the present study of subsurface samples from the Black Sea. Because of the large number of samples and the great amount of reworking, the scanning microscope was not much used.

Bukry (1974) described the calcareous nannoplankton found in the upper 12 meters of cores collected by the R/V Atlantis, Cruise 49, in the Black Sea. He described three floras which he differentiated into three units: Unit 1, dominated by Holocene coccoliths; Unit 2 containing a mixture of Holocene, Eocene, and Cretaceous coccoliths; and Unit 3 containing only reworked Eocene and Cretaceous coccoliths. His Unit 1 is dominated by Emiliania huxleyi (Lohmann); in the present samples, Unit 1 is recognized only in the corecatcher sample of Core 1 of Hole 379. Unit 2 was not observed in any samples examined from the three sites. Unit 3 was the most common assemblage observed, being present in most samples from Sites 379, 380, and 381. During the study, the author noted two additional nannofloras, a Gephyrocapsa caribbeanica flora and a Braarudosphaera bigelowi flora, both floras being characterized by the nominal species. In the case of the former, other indigenous species may be present, but in the case of the Braarudosphaera bigelowi flora, no other indigenous species are present. Many reworked Cretaceous and Eocene to Oligocene species of calcareous nannoplankton are present. Only the
Emiliania huxleyi and Gephyrocapsa caribbeanica floras can be dated. The former is late Quaternary in age and belongs to the NN 21 Emiliania huxleyi Zone of Martini (1971). The latter is Quaternary in age.

The Gephyrocapsa caribbeanica flora was found throughout the cored interval above Section 6, Core 11, of Hole 379A. Abundances of the flora ranged from the very rare to floods (Figure 1). Where occurring in floods, much of the clay size fraction consisted of this species. This flora was also found in the interval above Section 3, Core 10, at Site 380 (Figure 2). As at Site 379, the general abundance of the flora ranged from very rare to floods; in the latter instances, again, much of the clay size fraction was comprised of this species. This flora was not present at Site 381 (Figure 3). According to Bukry's (1974) usage, the paleoenvironment of this flora probably represents brackish water.

The Braarudosphaera bigelowi flora was encountered in Sections 2 and 3 of Core 25 of Hole 379A (Figure 1). The only indigenous species present was Braarudosphaera bigelowi (Gran and Braarud), but rare, reworked Cretaceous and Eocene to Oligocene species of calcareous nannoplankton are present. Braarudosphaera bigelowi occurs as rare whole specimens and fragments in Sample 379A-25-2, 50-52 cm and as abundant whole specimens and fragments in Sample $379 \mathrm{~A}-25-3,134-135 \mathrm{~cm}$, associated with reworked Cretaceous and Eocene to Oligocene species. Several questionable occurrences, based on rare whole specimens, were observed in Samples 379A-19-5, 99$101 \mathrm{~cm}, 379 \mathrm{~A}-21, \mathrm{CC}$, and 379A-51, CC. At Site 380, B. bigelowi occurred rarely as whole and fragmented 

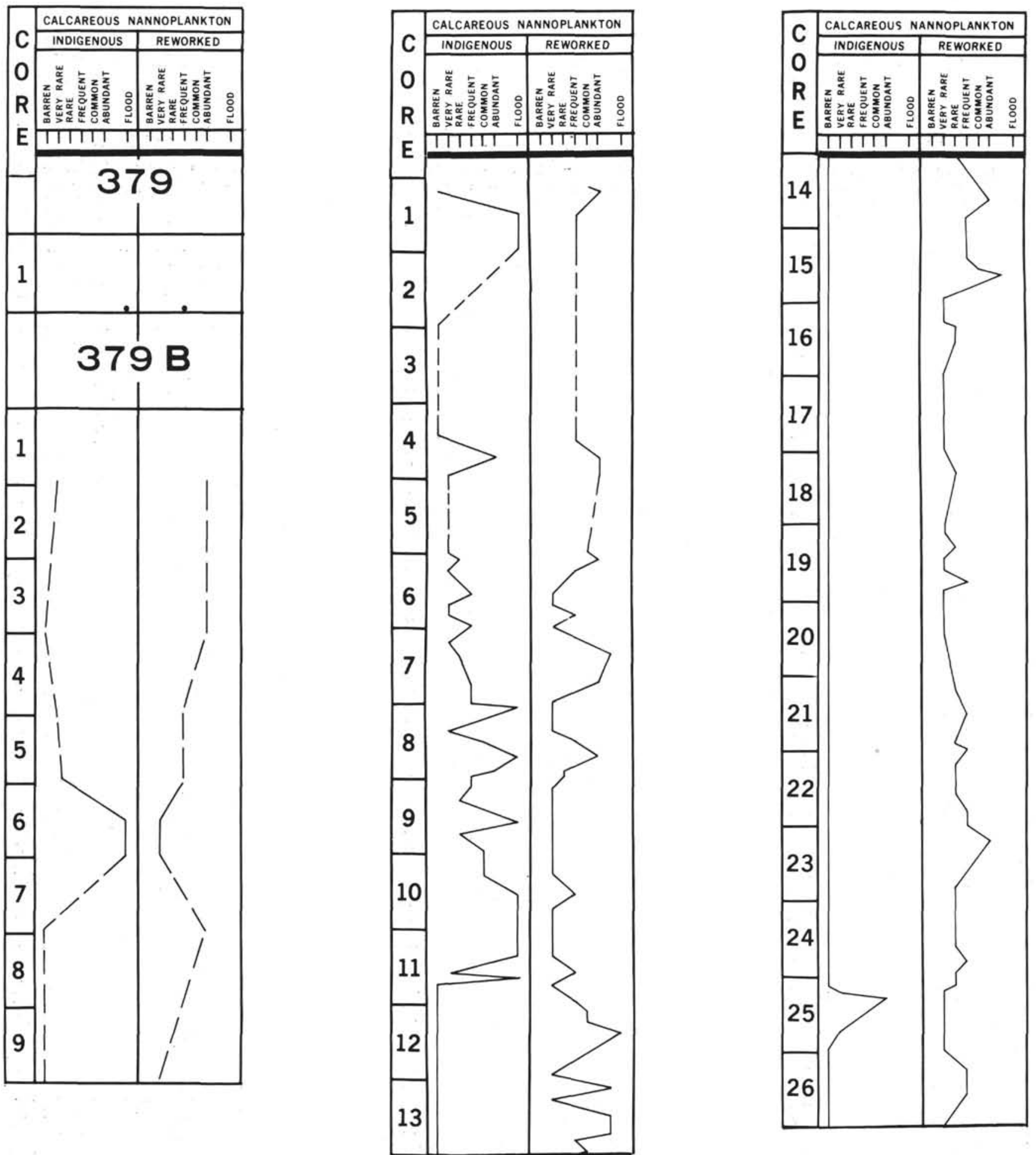

Figure 1. Distribution of calcareous nannoplankton in Holes 379, 379A, and $379 \mathrm{~B}$.

specimens in Core 36, Samples 380-36-2, 77-79 cm, 380$36-3,82-84 \mathrm{~cm}$, and 380-36, CC, together with reworked older species (Figure 2). In Hole 380A, it occurred in the interval from $380 \mathrm{~A}-55$, CC through $380 \mathrm{~A}-57, \mathrm{CC}$, but of the nine samples examined, it occurred in only four samples: 380A-55, CC (rare),
380A-56-4, 136-138 cm (flood), 380A-56, CC (common), and 380A-57, CC (frequent). At Site 381, B. bigelowi was found in five samples, 381-36, CC (very rare), 381-37-2, 116-118 cm (flood), 381-37-5, 112-114 $\mathrm{cm}$ (frequent), 381-37, CC (flood), and 381-38, CC (common), in the interval from Cores 36 through 38 , as 
HOLE 379 A
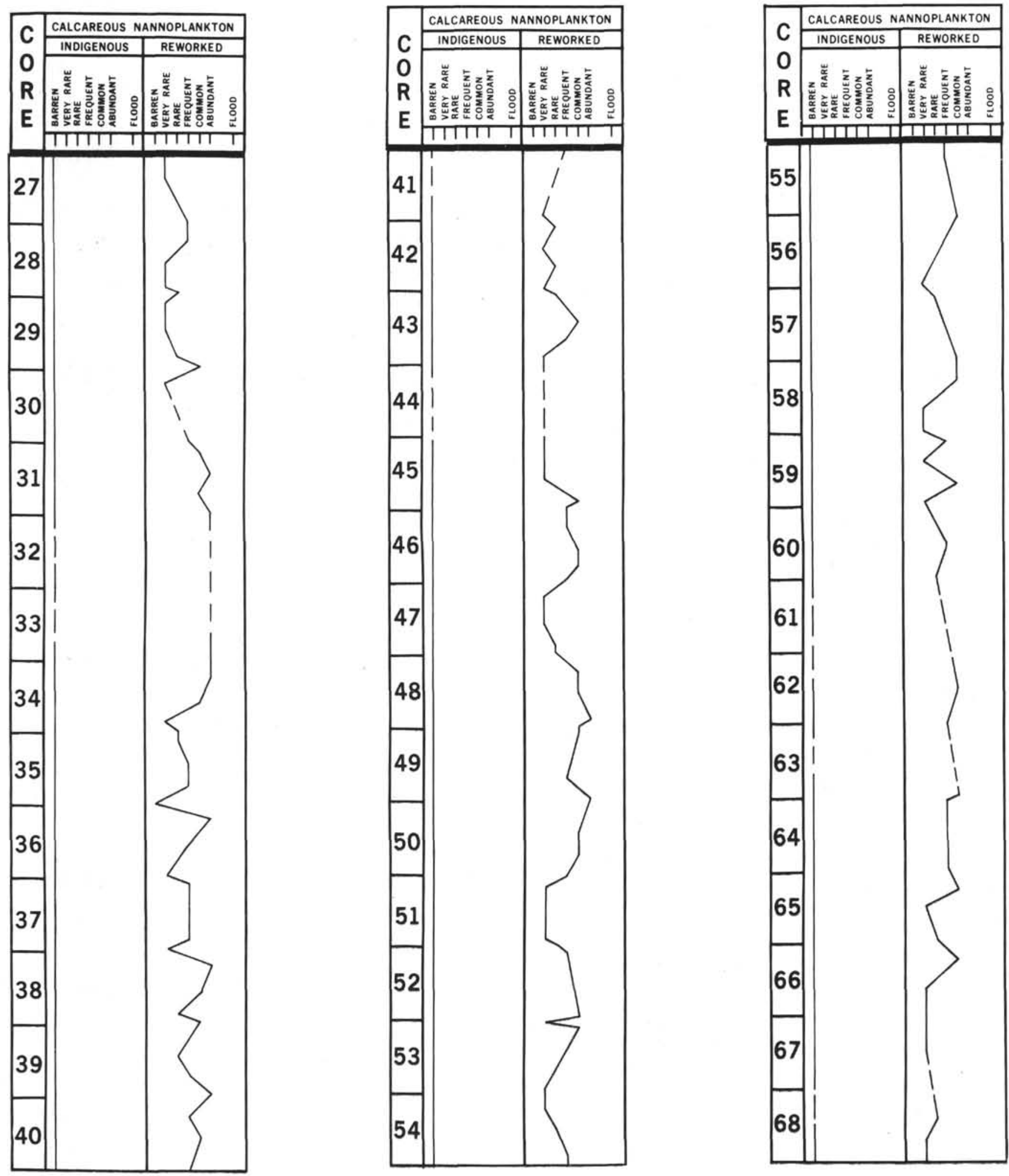

Figure 1. (Continued)

complete and fragmented specimens associated with reworked older species (Figure 3).

On the basis of its presence in the modern Black Sea and the Gulf of Panama, the paleoenvironment for
Braarudosphaera bigelowi (Gran and Braarud) is one of lowered salinities (Bukry, 1974). Also, the absence of Ceratolithus cristatus Kamptner, Gephyrocapsa oceanica Kamptner, Helicopontosphaera kamptneri Hay 


\section{HOLE 380}
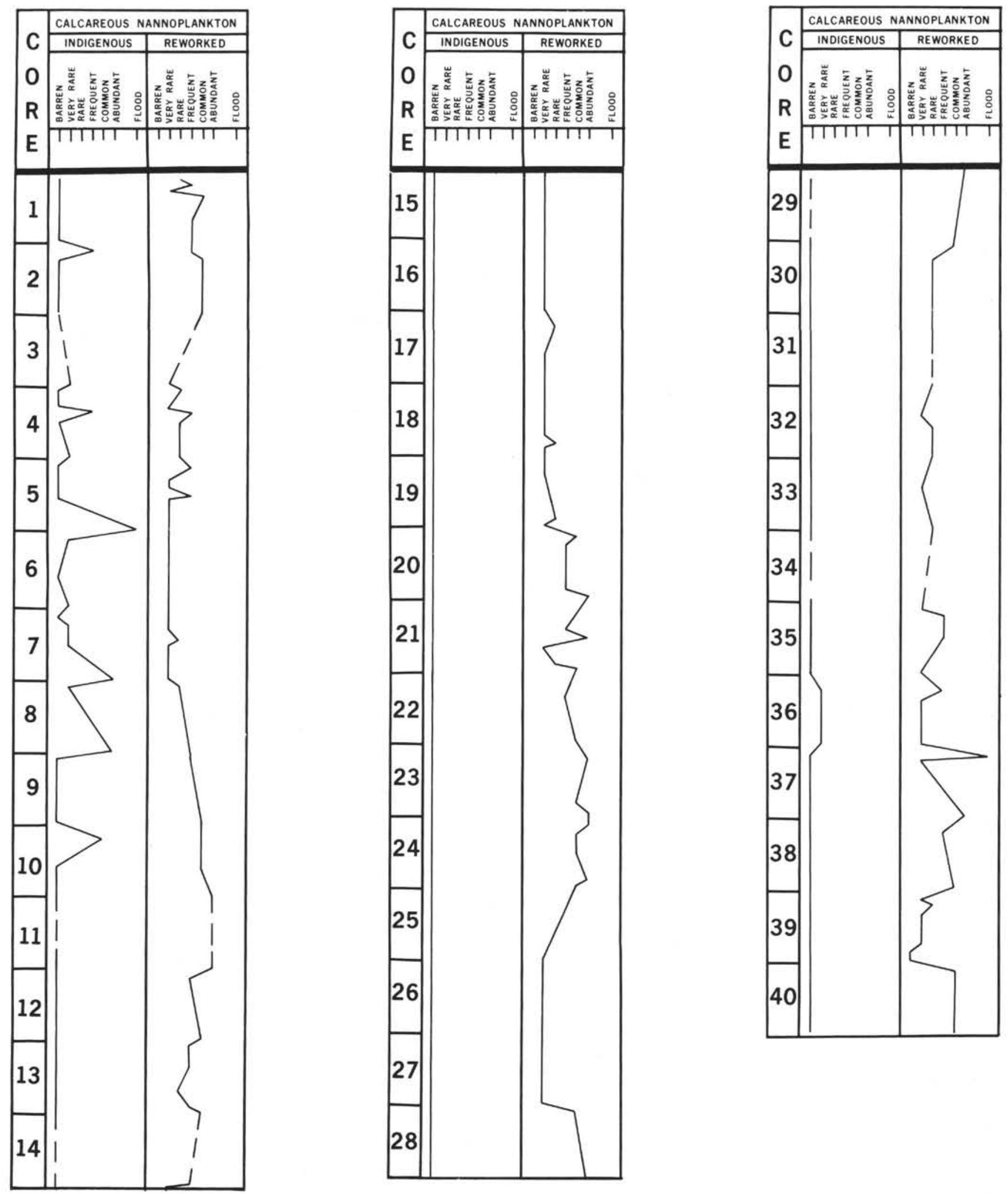

Figure 2. Distribution of calcareous nannoplankton in Holes 380 and $380 \mathrm{~A}$.

and Mohler, and Rhabdosphaera stylifera Lohmann, which Bukry (1974) considers typical marine species, would indicate a brackish water paleoenvironment.
Braarudosphaera bigelowi ranges stratigraphically from Jurassic to Recent, and cannot be used to determine the age of zonal assignment of the interval in which it is 


\section{HOLE 380 A}
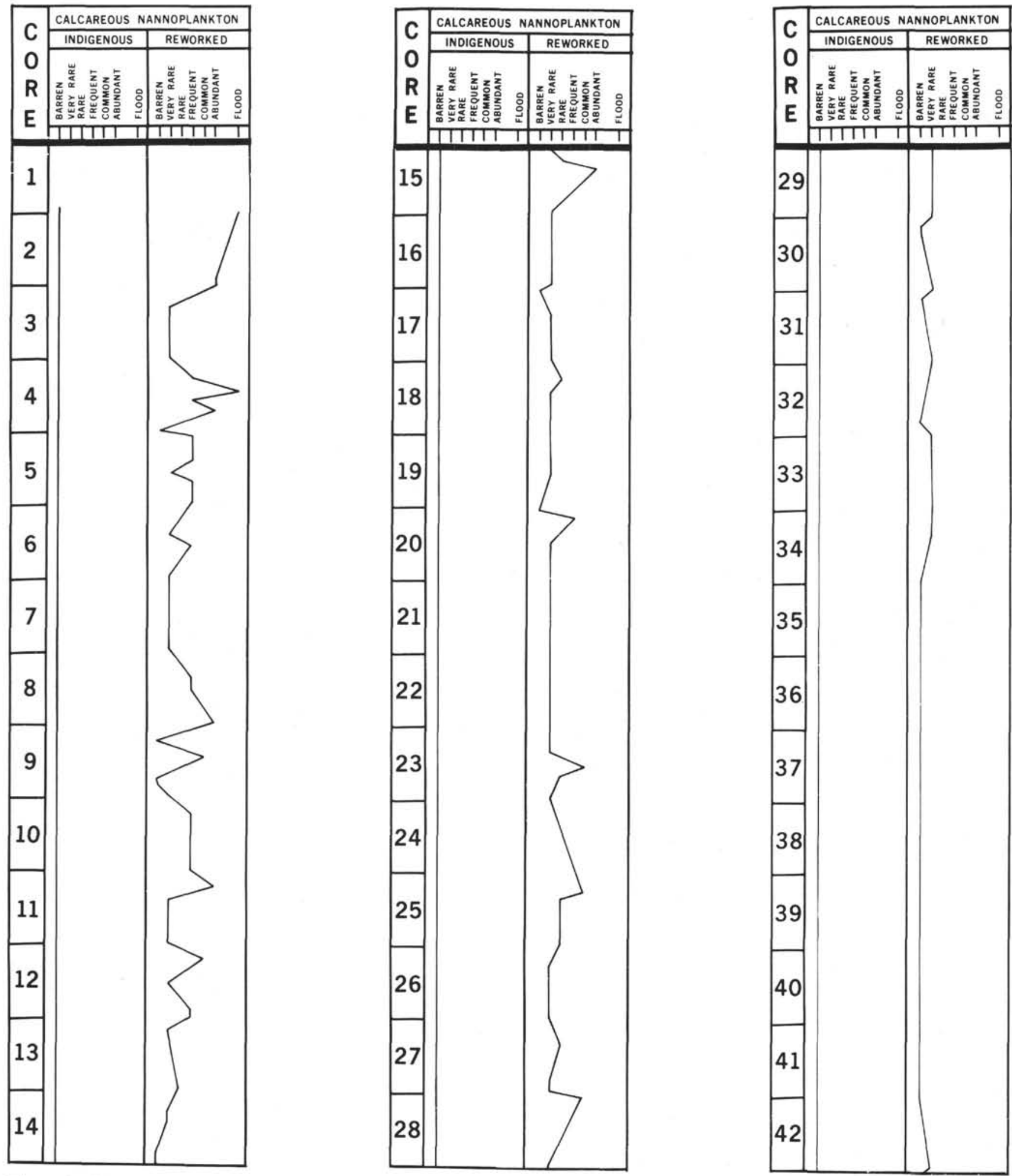

Figure 2. (Continued)

found. Reworked species are common in most samples from cores recovered from Sites 379, 380, and 381 (Figure 1). At Site 379, about 110 different reworked species of calcareous nannoplankton were identified. Most of the species were derived from Cretaceous and Eocene to Oligocene age strata. The most common 


\section{HOLE 380 A}
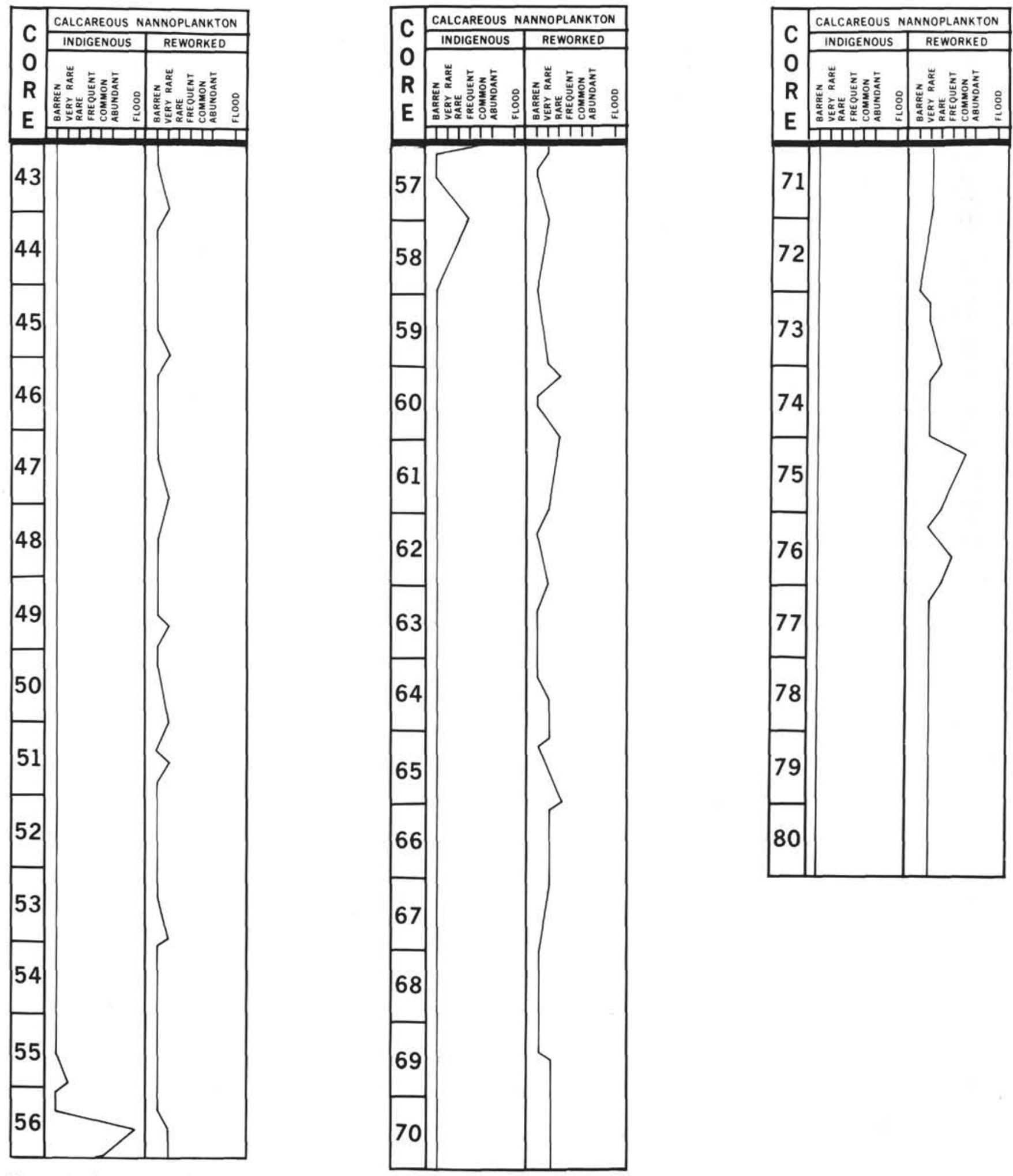

Figure 2. (Continued)

Cretaceous species, in order of decreasing frequency, are Watznaueria barnesae (Black), Arkhangelskiella cymbiformis Vekshina, Cretarhabdus crenulatus
Bramlette and Martini, Eiffellithus turriseiffelli Deflandre, Prediscosphaera cretacea (Arkhangelsky), Micula decussata Vekshina, Cribrosphaerella ehren- 
HOLE 381
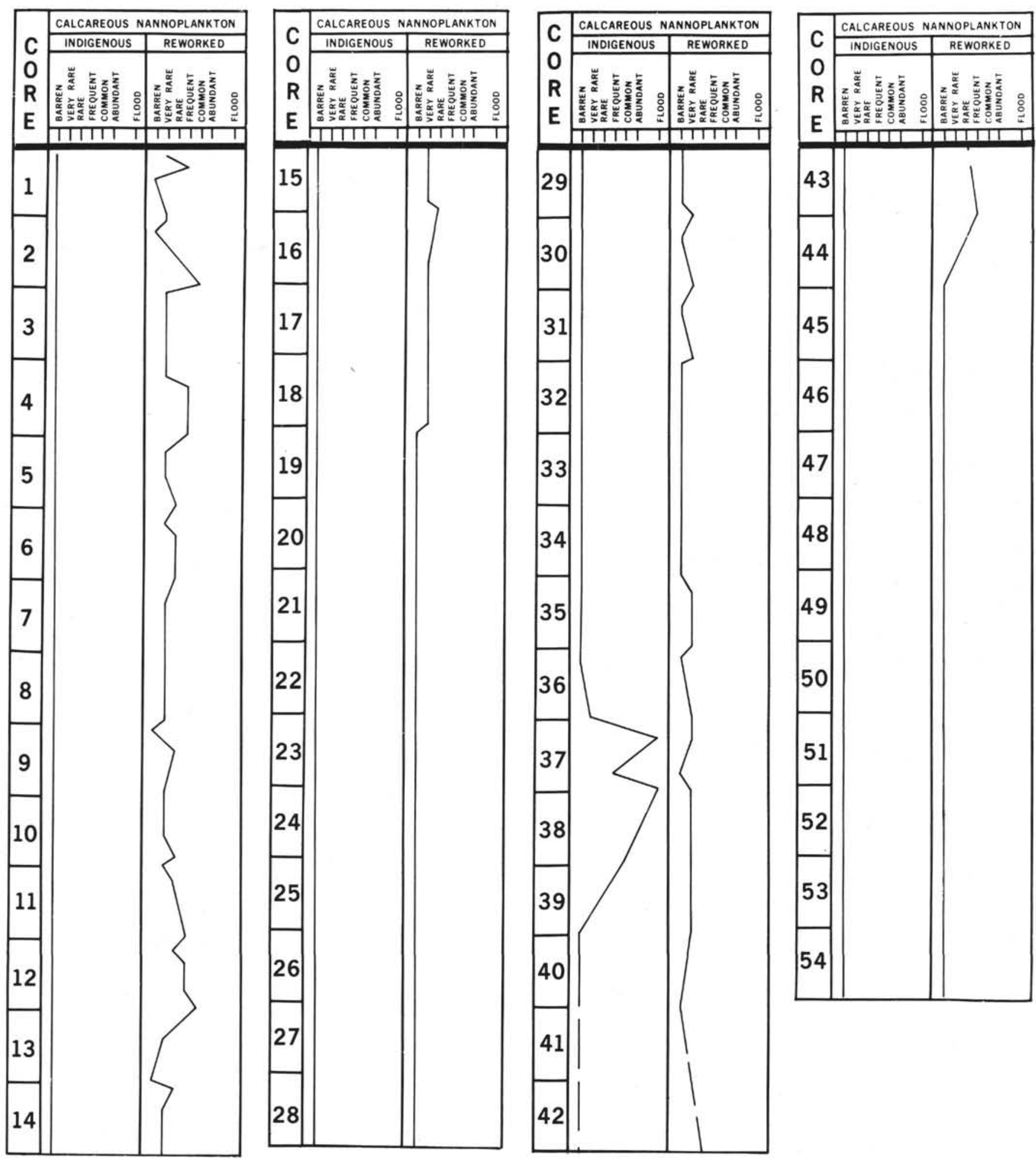

Figure 3. Distribution of calcareous nannoplankton in Hole 381.

bergi Arkhangelsky), Microhabdulus decoratus Deflandre, Broinsonia parca (Stradner), Microhabdulus stradneri Bramlette and Martini, and Eiffellithus augustus Bukry. Less frequently occurring Cretaceous species are Kamptnerius magnificus Deflandre and Zygodiscus spiralis Bramlette and Martini. Coccolithus pelagicus (Wallich) is the most common Tertiary species observed. Although less common than the 
Cretaceous forms, Eocene to Oligocene species are next in order of occurrence. Of the Eocene to Oligocene species encountered, in order of decreasing frequency, are Cyclococcolithina neogammation (Bramlette and Wilcoxon), Cyclococcolithina formosa (Kamptner), Dictyococcites scrippsae Bukry and Percival, Dictyococcites bisectus (May, Mohler, and Wade), Reticulofenestra umbilica (Levin), Reticulofenestra spp., Discoaster deflandrei Bramlette and Riedel, and Isthmolithus recurvus Deflandre. Definite Eocene calcareous nannoplankton species commonly found, in order of decreasing frequency, are Chiasmolithus grandis Bramlette and Riedel, Discoaster lodoensis Bramlette and Riedel, Micrantholithus spp., Discoaster barbadiensis Tan, Helicopontosphaera seminulum (Bramlette and Sullivan), Chiasmolithus solitus (Bramlette and Sullivan), Helicopontosphaera lophota (Bramlette and Sullivan), Micrantholithus crenulatus Bramlette and Sullivan, and Marthasterites tribrachiatus Bramlette and Riedel. The Paleocene to Eocene species, Sphenolithus radians Deflandre, occurs frequently. A few occurrences of Discoaster multiradiatus Bramlette and Riedel, a Paleocene form, were also noted. The Miocene species, Helicopontosphaera ampliaperta (Bramlette and Wilcoxon), occurred in a few samples, and Discoaster brouweri? Tan was observed in one sample. Although many other species were present, their rarity precludes citing them here.

At Site 380, about 80 different species of reworked calcareous nannoplankton were recorded (Figure 2). As at Site 379, Cretaceous and Eocene to Oligocene species are the most frequent, including the Cretaceous species, in order of decreasing frequency, Watznaueria barnesae (Black), Arkhangelskiella cymbiformis Vekshina, Prediscosphaera cretacea (Arkhangelsky), Micula decussata Vekshina, Eiffellithus turriseiffelli Deflandre, Cretarhabdulus crenulatus Bramlette and Martini, Eiffellithus augustus Bukry, Kamptnerius magnificus Deflandre, Cribrosphaerella ehrenbergi Arkhangelsky, and Broinsonia parca (Stradner). The Tertiary form, Coccolithus pelagicus (Wallich), is prevalent, as are the Eocene to Oligocene species, in order of decreasing abundance, Reticulofenestra spp., Cyclococcolithina neogammation (Bramlette and Wilcoxon), Dictyococcites scrippsae Bukry and Percival, Dictyococcites bisectus (Hay, Mohler, and Wade), and Discoaster deflandrei Bramlette and Riedel. Rare occurrences of definite Eocene forms, such as Chiasmolithus solitus (Bramlette and Sullivan), Cyclococcolithina reticulatus (Gartner and Smith), Discoaster barbadiensis Tan, and Discoaster lodoensis Bramlette and Riedel, were also observed. A few Miocene species, Helicopontosphaera ampliaperta (Bramlette and Wilcoxon), Sphenolithus heteromorphus Bramlette and Wilcoxon, and Discoaster exilis Martini and Bramlette, are rarely represented. The Miocene to Pliocene species, Discoaster brouweri Tan, occasionally was present.

At Site 381, the occurrence of reworked calcareous nannoplankton species was not as prevalent as at Sites 379 and 380 (Figure 3). Fifty-six reworked species were recorded from this site, occurring in approximately one-half of the samples examined. Of the Cretaceous species, in order of decreasing frequency, are Watznaueria barnesae (Black), Eiffellithus turriseiffeli Deflandre, Micula decussata Vekshina, Prediscosphaera cretacea (Arkhangelsky), Arkhangelskiella cymbiformis Vekshina, Broinsonia parca (Stradner), and Cretarhabdus crenulatus Bramlette and Martini; of Tertiary species was Coccolithus pelagicus (Wallich). Eocene to Oligocene species, in order of decreasing frequency, are Cyclococcolithina neogammation (Bramlette and Wilcoxon), Dictyococcites scrippsae Bukry and Percival, Reticulofenestra spp., Cyclococcolithina formosa (Kamptner), Dictyococcites bisectus (Hay, Mohler, and Wade), and Reticulofenestra umbilica (Levin).

\section{ACKNOWLEDGMENTS}

I would like to acknowledge both Dr. L.B. Gibson and Mr. R.W. Morin of our Stratigraphic Laboratory for their constructive criticism of my contribution.

\section{REFERENCES}

Bukry, D., 1974. Coccoliths as paleosalinity indicators-evidence from Black Sea. In Degens, E.T. and Ross, D.A. (Eds.), The Black Sea-geology, chemistry, and biology: Am. Assoc. Petrol. Geol. Mem. 2, p. 353-363.

Martini, E., 1971. Standard Tertiary and Quaternary calcareous nannoplankton zonation: Second Plank. Conf. Proc., Rome, v. 2, p. 739-785.

\section{PLATE 1}

Scanning electron micrographs taken by

Mr. J.J. Porter, Mobil Research and Development Corporation, Field Research Laboratory, Dallas, Texas

Figure 1

Geophyrocapsa caribbeanica Boudreaux and Hay. 3550×, Sample 379A-11-2, 13-15 cm, Gephyrocapsa caribbeanica flora.

Figure 2

Gephyrocapsa caribbenaica Boudreau and Hay. 5000×, Sample 379A-11-2, $13-15 \mathrm{~cm}$, Gephyrocapsa caribbeanica flora.
Figure 3

Figure 4

Coccosphere of Gephyrocapsa caribbeanica Boudreaux and Hay. 8200×, Sample 379A-11-2, 13-15 cm, Gephyrocapsa caribbeanica flora.

Braarudoshpaera bigelowi (Gran and Braarud). 5000×, Sample 381-37, CC, Braarudosphaera bigelowi flora. 
PLATE 1
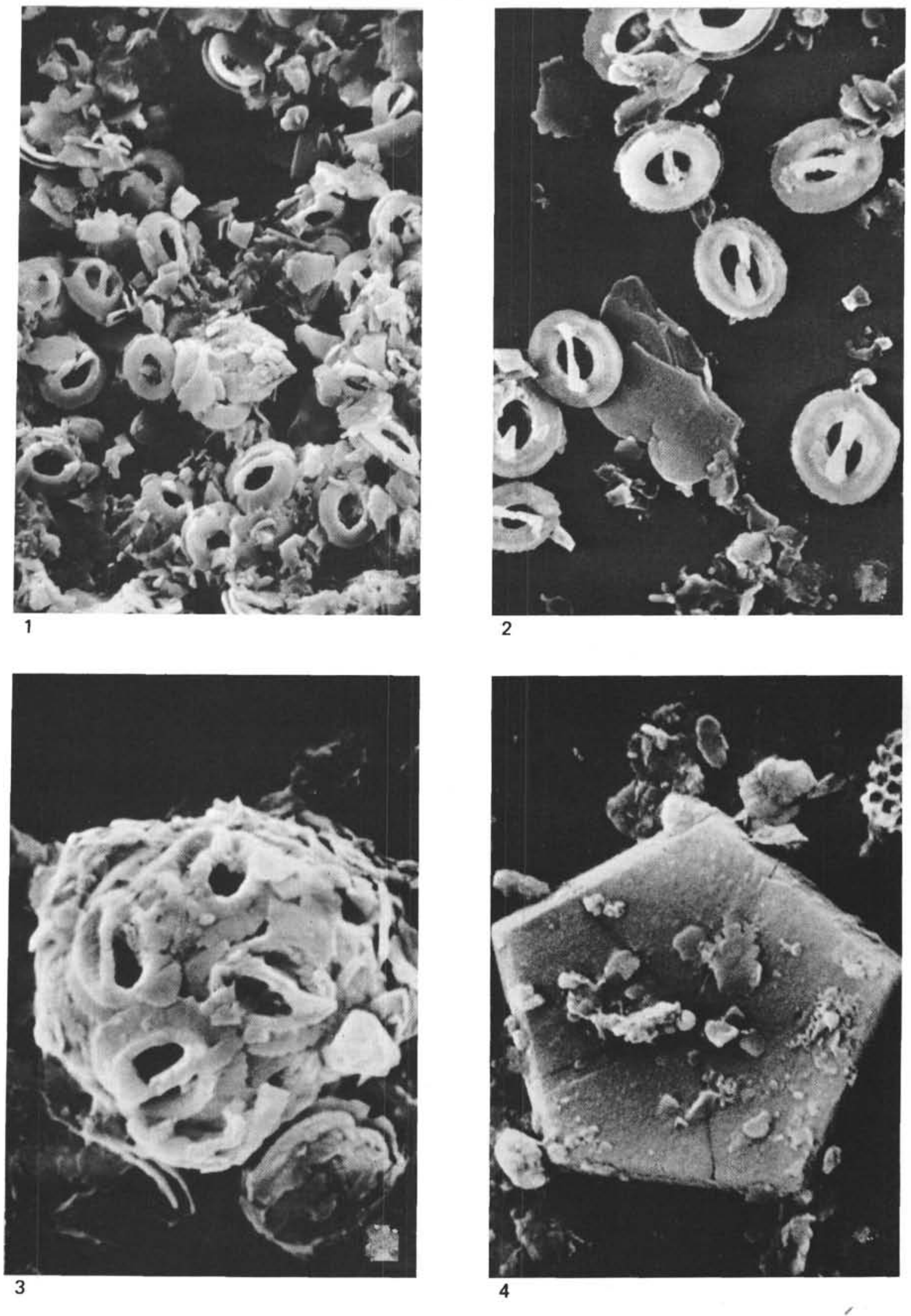